\title{
Investigation of Motor Abilities According to Gender in Children with Diplegic Cerebral Palsy
}

\section{Diplejik Serebral Palsili Çocuklarda Cinsiyete Göre Motor Becerilerin İncelenmesi}

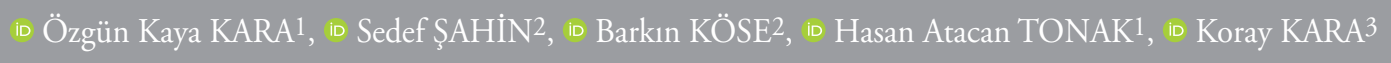

${ }^{1}$ Akdeniz University Faculty of Health Sciences, Department of Physiotherapy and Rehabilitation, Antalya, Turkey

2Hacettepe University Faculty of Health Sciences, Department of Occupational Therapy, Ankara, Turkey

3Univerity of Health Sciences Turkey, Gülhane Training and Research Hospital, Department of Child and Adolescent Mental Health and

Diseases, Ankara, Turkey

\section{ABSTRACT}

Objective: The aim of this study was to compare the fine and gross motor skills of children with diplegic cerebral palsy (CP) according to gender.

Methods: This study included 73 children with diplegic CP (39 males, mean age: $8.76 \pm 1.4$; 34 females mean age: $8.29 \pm 1.31$ years) aged between 6 to 12 years. Bruininks-Oseretsky Test 2-Short Form (BOT2-SF), consisting of 8 subtests and 12 items, was used to evaluate the gross and fine motor skills of children. Fine and gross motor skills of children with CP were compared with Student's t-test.

Results: According to gender, the BOT2-SF total score and fine motor precision, bilateral coordination and upper-limb coordination scores of sub-tests were statistically significant higher in girls than in boys $(\mathrm{p}<0.05)$.

Conclusion: The results of our current study reflect that fine and gross motor skills of girls with diplegic CP are better than boys. Physiotherapists and ergotherapists should first determine the fine and gross motor skill problems with objective measurement methods and especially consider the differences between genders when determining an integrated multi-factor therapeutic approach for children with diplegic CP.

Keywords: Diplegic, child, cerebral palsy, development, gender

\section{ÖZ}

Amaç: Bu çalışmanın amacı, diplejik serebral palsili (SP) çocuklarda cinsiyete göre ince ve kaba motor becerileri karşılaştırmaktır.

Yöntemler: Çalışmaya yaşları 6 ile 12 yaşları arasında değişen, 73 diplejik (39 erkek, ortalama yaş: 8,76 1,4 ; 34 kız ortalama yaş: $8,29 \pm 1,31)$ SP'li çocuk dahil edildi. Çocukların kaba ve ince motor becerilerini değerlendirmek için 8 alt test ve 12 maddeden oluşan Bruininks-Oseretsky Test 2- Kısa Form (BOT2-KF) kullanıldı. Kız ve erkek SP'li çocukların ince ve kaba motor becerileri Student t-testi kullanılarak karşılaştırıldı.

Bulgular: Cinsiyete göre BOT2-KF toplam skoru ve alt testlerinden ince motor doğruluk, bilateral koordinasyon ve üst ekstremite koordinasyon skorları kızlarda erkeklere göre istatistiksel olarak anlamlı derecede yüksekti $(\mathrm{p}<0,05)$.

Sonuç: Güncel çalışmamızın sonuçları, diplejik SP'li kız çocukların ince ve kaba motor becerilerinin erkeklerden daha iyi olduğunu yansıtmaktadır. Fizyoterapist ve ergoterapistlerin, diplejik SP'li çocuklar için çok faktörlü entegre terapatik bir yaklaşım belirlerken öncelikle çocukların ince ve kaba motor beceri problemlerini objektif ölçüm yöntemleri ile belirlemeleri ve özellikle cinsiyetler arasındaki farkları göz önünde bulundurmaları gerekmektedir.

Anahtar Sözcükler: Diplejik, çocuk, serebral palsi, gelişim, cinsiyet

Address for Correspondence: Özgün Kaya KARA, Akdeniz University Faculty of Health Sciences, Department of Physiotherapy and Rehabilitation, Antalya, Turkey

E-mail: ozgun_kaya@yahoo.com ORCID ID: orcid.org/0000-0002-7314-6436 


\section{Introduction}

Cerebral Palsy (CP), the most common cause of childhood physical impairment, is a group of permanent disorders in the development of posture and movement in the developing fetal or infant brain, causing activity limitation (1). In CP, motor disorders are often accompanied by sensorial, perceptional, cognitive, communicational and behavioral disorders, epilepsy and secondary musculoskeletal problems (2). Spastic diplegia is the most common type of $\mathrm{CP}$ with a rate of approximately $44 \%(3-5)$. In spastic diplegia seen as a result of perinatal hypoxic-ischemic lesion or periventricular leukomalacia, motor failure in the lower extremities is often more severe than in the upper extremities (3-5). Lack of gross and fine motor skills in children with diplegic CP due to non-progressive brain lesions and accompanying secondary pathologies (eg spasticity, muscle weakness, muscle contractures, increased co-contraction, decreased selective motor control) negatively affect daily life activities (6-8).

Motor development is expressed as the individual gaining of the mobility in parallel with the physical growth and the development of the central nervous system, and plays an important role in the recognition and management of the child's environment, gaining independence and ensuring social participation. In order to determine the motor development level of children with diplegic $\mathrm{CP}$ in the rehabilitation process and to organize appropriate rehabilitation programs, fine and gross motor skills should be evaluated in detail $(9,10)$. There are different tests, such as the Gross Motor Function Measurement (GMFM), Bruininks-Oseretsky Test of Motor Proficiency Second Edition (BOT-2), Bruininks-Oseretsky Test of Motor Proficiency Second Edition Short Form (BOT2-SF), Ability for Basic Movement Scale, Developmental Sequence of Fundamental Motor Skills Inventory and Test of Gross Motor Development (11-13). The tests to be used in the evaluation of motor ability in children with diplegic CP should be able to detect the lack of fine and gross motor development in the child, to show the child's highest performance, to be easily applicable and accessible $(13,14)$.

When the features of the motor skill tests are examined in general, BOT2-SF differs from other tests in terms of both its speedy application and easy availability of test materials (13). In addition, another feature that distinguishes BOT2-SF from other tests is the philosophy in creation of the test. Dr. Robert $\mathrm{H}$. Bruininks developed this test with the idea of developing a product that evaluates sensory-perception-motor performances rather than a test that evaluated only motor performance (15). The fact that the test has been developed with this perspective, it does not contain too many materials and its easy application makes BOT2-SF stand out in the evaluation process (14).

Few studies in the literature have investigated the difference in gross motor development between boys and girls with spastic diplegic CP. In a study by Romeo et al. (16) the development of $\mathrm{CP}$ in children with gross motor function was examined by using GMFM, and it was shown that girls' gross motor skill levels were better than boys. Similarly, it was concluded in the literature that in different studies investigating the difference in motor development between genders, girls had a better level of gross motor skills than boys (17-19). In the light of our up-todate information, no studies revealing the difference between gross and fine motor skills in boys and girls with diplegic CP with BOT2-SF have been found (4). The purpose of our study planned due to these limitations in the literature was to reveal the difference between the fine and gross motor skills of children with diplegic $\mathrm{CP}$ by using BOT2-SF.

\section{Methods}

Ethical approval was obtained from the Health Sciences University, Non-Interventional Research Ethics Committee (date: 16.10.2018, number: 18/249). The children and their families included in the study were given detailed information about the study and were informed.

Seventy eight children with diplegic CP aged between 6 and 12 years who were admitted to the hospital between November 2018 and March 2019, were included in the study. Criteria for inclusion in the study were; (1) Being diagnosed as having diplegic CP, (2) being in level I, II or III according to the Gross Motor Function Classification System (GMFCS), (3) having a cognitive level that could understand and apply verbal commands, and (5) not having a systemic problem and epileptic seizures that could not be controlled. Exclusion criteria were; (1) families and children who did not agree to participate in the study, (2) having undergone surgery or Botulinum Toxin application in the last 6 months, (3) taking place in levels IV and V according to the Hand Manual Ability Classification System (MACS). Three of the children with diplegic $\mathrm{CP}$ included in the study were excluded from the study because they had Botulinum Toxin-A injections, one was excluded due to undergoing a surgical procedure, and one was excluded due to having upper respiratory tract infection.

The BOT2-SF was used to evaluate the gross and fine motor skill levels of all children included in the study.

\section{The Bruininks-Oseretsky Test of Motor Proficiency, Second Edition, Short Form (BOT2-SF)}

The BOT was developed by Robert H. Bruininks in 1972 to measure the motor functions of children in the age group of 4.514.5 years, based on the Oseretsky Test of Motor Proficiency (11). The BOT was updated in 2005 and became BOT2. The BOT2 is a test with both short and long forms to evaluate motor skill levels in children aged 4 to 21 years (10). The validity and reliability of the BOT2 long form was made by Mülazimoğlu Ball 1 in 2012 (10), and the validity and reliability of the short form by Köse in 2018 (14). In our study, BOT2-SF consisting of 8 subtests and 12 items was used. The application period of the test, which evaluates the gross and fine motor skills of children, is on average 15-20 minutes. The subtests, items and scores of BOT2-SF are as follows:

- Fine Motor Precision (0-10 points)

$\diamond$ Filling in A Star (0-3 points)

$\diamond$ Drawing A Line Through A Path (0-7 points) 
- Fine Motor Integration (0-11 points)

$\diamond$ Copying Overlapping Circles (0-6 points)

$\diamond$ Copying Diamond (0-5 points)

- Manual Dexterity (0-9 points)

$\diamond$ Stringing Blocks (0-9 points)

- Bilateral Coordination (0-9 points)

$\diamond$ Touching the Tip of the Nose with Forefinger (Eyes Closed) (0-4 points)

$\diamond$ Creating a Square with the Index Finger and the Thumb (0-5 points)

- Balance (0-4 points)

$\checkmark$ Walking Forward on A line (0-4 points)

- Running Speed and Agility (0-10 points)

$\diamond$ One Legged Stationary Hop (0-10 points)

- Upper-Limb Coordination (0-12 points)

$\diamond$ Catching the Throwed Ball (One Hand) (0-5 points)

$\diamond$ Dribbling A Ball (0-7 points)

- Strength (0-9 points)

$\diamond$ Knee Push-Ups (For Boys) (0-9 points)

$\diamond$ Sit Ups ( For Girls ) (0-9 points).

\section{Statistical Analysis}

Windows based SPSS (IBM SPSS Statistics, Version 23.0, Armonk, NY, USA) package program was used in the statistical analysis of the data obtained in our study. In the representation of the descriptive statistics of the data obtained from the subjects participating in the study, the data that fit the normal distribution as a measure of central tendency were given as mean \pm standard deviation, and the data that did not fit to the normal distribution were given as median (25-75\%). Analytical (Kolmogorov-Smirnov/Shapiro-Wilks test) and visual (Histogram and probability graphs) methods were used to test the compliance of the data to normal distribution. In order to measure the statistical significance of the difference between girls and boys, Student t-test was used in normally distributed data groups. In our study, statistical significance level was accepted as $\mathrm{p}<0.05$.

\section{Results}

A total of 73 children with diplegic CP (39 boys, 34 girls) with an average age of $8.54 \pm 1.37$ years were included in our study. Right extremity of $45.2 \%$ of the children was dominant and left extremity of $54.8 \%$ was dominant. Girls' weight and body mass index were statistically significantly lower than boys. The demographic characteristics of all diplegic CP children included in the study are presented in Table 1.
When the BOT2-SF results were compared by gender, it was found that girls with diplegic $\mathrm{CP}$ scored significantly higher than boys with diplegic $\mathrm{CP}$ in terms of fine motor precision, bilateral coordination, upper-limb coordination subtests and total score $(\mathrm{p}<0.05)$ (Table 2).

\section{Discussion}

In our study where we examined the fine and gross motor skills of children with diplegic CP using BOT2-SF; it was found that girls with diplegic $\mathrm{CP}$ scored significantly higher than boys with diplegic $\mathrm{CP}$ in terms of fine motor precision, bilateral coordination, upper-limb coordination subtests and total score. Especially, in our study where only fine and gross motor skills of children with diplegic SP were evaluated, the use of BOT2-SF in evaluation and the difference found between genders according to this evaluation distinguished our study from other studies.

The localization and severity of the lesion in the brain affect fine and gross motor skills of children with CP. These children try to perform daily life activities despite the limitations in their fine and gross motor skills (20). Although there are studies in the literature evaluating the fine and gross motor skills of children in all subgroups of healthy children and CP $(4,6,17)$, there are not many studies evaluating the motor skills of children with diplegic CP only. In these studies, it was observed that the children with diplegic SP were not compared in terms of fine and gross motor skills specifically by gender $(9,21,22)$. In the studies reviewed, it was found that either comparisons were made between all the subgroups of $\mathrm{CP}$ or they examined the differences between healthy children. Related studies concluded that children with normal development had better gross and fine motor skills than children with CP (9). However, the evaluation methods they frequently used when evaluating motor skills were GMFM, MACS, Bimanual Fine Motor Function and GMFCS $(4,6,9,21,22)$. In our current study, we used BOT2-

Table 1. Children's demographic features

\begin{tabular}{|c|c|c|c|c|c|}
\hline Variables & \multicolumn{2}{|c|}{$\begin{array}{l}\text { Girl } \\
(n=34)\end{array}$} & \multicolumn{2}{|c|}{$\begin{array}{l}\text { Boy } \\
(n=39)\end{array}$} & $\mathrm{p}^{\mathrm{a}, \mathrm{b}}$ \\
\hline Age (year) (Mean \pm SD) & \multicolumn{2}{|c|}{$8.29 \pm 1.31$} & \multicolumn{2}{|c|}{$8.76 \pm 1.4$} & $0.14^{\mathrm{a}}$ \\
\hline Height (cm) & \multicolumn{2}{|c|}{$127.05 \pm 9.81$} & \multicolumn{2}{|c|}{$130.56 \pm 5.36$} & $0.05^{\mathrm{a}}$ \\
\hline Weight (kg) & \multicolumn{2}{|c|}{$27.35 \pm 6.26$} & \multicolumn{2}{|c|}{$30.33 \pm 4.85$} & $0.02^{\mathrm{a}}$ \\
\hline BMI $\left(\mathrm{kg} / \mathrm{m}^{2}\right)$ & \multicolumn{2}{|c|}{$16.7 \pm 1.74$} & \multicolumn{2}{|c|}{$17.67 \pm 1.68$} & $0.01^{\mathrm{a}}$ \\
\hline GMFCS & $n$ & $\%$ & $n$ & $\%$ & $0.78^{\mathrm{b}}$ \\
\hline Level 1 & 8 & 23.5 & 7 & 17.9 & \\
\hline Level 2 & 11 & 32.4 & 12 & 30.8 & \\
\hline Level 3 & 15 & 44.1 & 20 & 51.3 & \\
\hline MACS & & & & & $0.11^{\mathrm{b}}$ \\
\hline Level 1 & 21 & 61.8 & 30 & 76.9 & \\
\hline Level 2 & 12 & 35.3 & 6 & 15.4 & \\
\hline Level 3 & 1 & 2.9 & 3 & 7.7 & \\
\hline
\end{tabular}

$\mathrm{p}^{\mathrm{a}}$ : Student's t-test, $\mathrm{p}^{\mathrm{b}}$ :Chi-square test, SD: Standard deviation, BMI: Body mass index, GMFCS: Gross Motor Function Classification System, MACS: Hand Manual Ability Classification System 
Table 2. Comparison of the Bruininks-Oseretsky Test 2-Short Form results by gender

\begin{tabular}{|c|c|c|c|c|c|c|}
\hline \multirow[t]{2}{*}{ BOT2-SF } & \multicolumn{2}{|c|}{$\begin{array}{l}\text { Girls with diplegic CP } \\
(n=34)\end{array}$} & \multicolumn{2}{|c|}{$\begin{array}{l}\text { Boys with diplegic CP } \\
(n=39)\end{array}$} & \multirow[t]{2}{*}{$\mathrm{t}$} & \multirow[t]{2}{*}{$\mathrm{P}^{\mathrm{a}}$} \\
\hline & $\bar{x} \pm S D$ & $(\min -\max )$ & $\bar{x} \pm S D$ & $(\min -\max )$ & & \\
\hline Fine motor precision & $1.76 \pm 1.04$ & $(0-3)$ & $1.25 \pm 0.96$ & $(0-4)$ & -2.15 & $0.03 *$ \\
\hline Fine motor integration & $5.32 \pm 1.90$ & $(3-9)$ & $4.58 \pm 1.44$ & $(2-8)$ & -1.86 & 0.06 \\
\hline Manual dexterity & $1.64 \pm 1.32$ & $(0-4)$ & $1.17 \pm 0.94$ & $(0-3)$ & -1.75 & 0.08 \\
\hline Bilateral coordination & $1.26 \pm 1.18$ & $(0-4)$ & $0.74 \pm 0.81$ & $(0-3)$ & -2.20 & $0.03 *$ \\
\hline Balance & $0.97 \pm 0.90$ & $(0-3)$ & $0.79 \pm 0.76$ & $(0-3)$ & -0.89 & 0.37 \\
\hline Running speed and agility & $0.61 \pm 0.77$ & $(0-3)$ & $0.35 \pm 0.62$ & $(0-2)$ & -1.57 & 0.12 \\
\hline Upper-limb coordination & $1.20 \pm 1.29$ & $(0-5)$ & $0.66 \pm 0.62$ & $(0-2)$ & -2.31 & $0.02 *$ \\
\hline Strength & $0.41 \pm 0.65$ & $(0-2)$ & $0.20 \pm 0.40$ & $(0-1)$ & -1.63 & 0.10 \\
\hline Total & $13.2 \pm 8.15$ & $(3-30)$ & $9.76 \pm 5.77$ & $(2-25)$ & -2.09 & $0.04 *$ \\
\hline
\end{tabular}

SF, which was developed with the idea of producing a product that evaluated sensory-perception-motor performances rather than just a test that evaluated motor performance, apart from these tests frequently used in the literature. It has become more valuable in defining how motor development changes in children with diplegic $\mathrm{CP}$ depending on gender, using more specific assessment tools, obtaining more objective results and providing more objective results in creating appropriate physiotherapy interventions (23).

Motor skill disorders faced by children with CP affect individuals in different clinical types of $\mathrm{CP}$, which is a highly heterogeneous group, to different degrees (24). In our current study children with diplegic CP with GMFCS levels I, II and III were included and a homogenous group was formed. Romeo et al. (16) evaluated in their study the gross motor skills of 171 children with $\mathrm{CP}$, including 73 girls with $\mathrm{CP}$ with an average age of $4.6 \pm 2.4$ years, and 98 boys with CP with an average age of $4.3 \pm 2.3$ years and found that girls' GMFM scores were higher than boys $(55 \%$ vs. $29 \%$ ). However, in that study, they evaluated children with hemiplegic, diplegic and quadriplegic CP. The results of our current study supported the findings of Romeo et al. (16) and our results proved that girls with diplegic $\mathrm{CP}$ had better fine and gross motor skills than boys.

Overall, research in the literature reflects that girls with CP have better fine and gross motor skills than boys $(16,25)$. Romeo et al. (25) concluded that girls were $89 \%$ better than boys in the standing subdivision of GMFM in another study of them where they investigated the gross motor functions of boys and girls with CP based on GMFCS levels. In our study, in parallel with these studies, there was an increase in favor of girls by $40.80 \%$ in the fine motor precision subtest, $70.27 \%$ in the bilateral coordination subtest, $81.81 \%$ in the upper-limb coordination subtest, and $35 \%$ in the total score of BOT2-SF. Possible explanations for this situation by Romeo et al. (16) were the neuroprotective effect of female hormones and different histomorphological features between the two genders. The fact that women have larger neuropil areas with more synaptic connections and more common dendritic arborization than men which can mediate better reorganization after a lesion and thus, girls with CP may have better fine and gross motor skills than boys, is supported by studies $(23,26,27)$.

\section{Study Limitations}

The limitations of our study were not including children with diplegic CP with GMFCS levels IV and V and lack of control group consisting of healthy children. In the future, there is a need for studies that present the difference in the development of children with CP by gender by comparing them with healthy peers in larger groups.

In children with $\mathrm{CP}$, the limitation in fine and gross motor skills affects the child's relationship with the environment and his/ her physical abilities. This problem can lead to a decrease in the learning and experiencing of the child with diplegic $\mathrm{CP}$ and as a result may affect the child's ability to live independently $(28,29)$. In the light of our current findings, it is important to consider the differences between girls and boys in rehabilitation programs so that children with diplegic $\mathrm{CP}$ can increase their participation in daily life activities.

\section{Conclusion}

As a result, physiotherapists need to make a good assessment about the problems of children with $\mathrm{CP}$ in fine and gross motor skills and collect evidence so that they can offer a multi-factor integrated therapeutic approach for children with diplegic CP. According to our current study, where we revealed genderspecific differences in children with diplegic CP; evaluating the development of fine and gross motor skills in children with diplegic SP would be the main building block for planning appropriate rehabilitation programs specific to the child. 


\section{Ethics}

Ethics Committee Approval: Ethical approval was obtained from the Health Sciences University, Non-Interventional Research Ethics Committee (Date: 16.10.2018, number: 18/249).

Informed Consent: The children and their families included in the study were given detailed information about the study and were informed.

Peer-review: Externally peer reviewed.

\section{Authorship Contributions}

Surgical and Medical Practices: K.K., Concept: Ö.K.K., S.Ş., Design: Ö.K.K, S.Ş., K.K., Data Collection or Processing: B.K., H.A.T., Analysis or Interpretation: K.K., B.K., S.Ş., Ö.K.K., Literature Search: B.K., H.A.T., Writing: Ö.K.K.

Conflict of Interest: No conflict of interest was declared by the authors.

Financial Disclosure: The authors declared that this study received no financial support.

\section{References}

1. Rosenbaum P, Paneth N, Leviton A, Goldstein M, Bax M, Damiano $\mathrm{D}$, et al. A report: the definition and classification of cerebral palsy April 2006. Dev Med Child Neurol Suppl 2007;109:8-14.

2. Arneson CL, Durkin MS, Benedict RE, Kirby RS, Yeargin-Allsopp M, Van Naarden Braun K, et al. Prevalence of cerebral palsy: Autism and Developmental Disabilities Monitoring Network, three sites, United States, 2004. Disabil Health J 2009;2:45-8.

3. Rose J, Wolff DR, Jones VK, Bloch DA, Oehlert JW, Gamble JG. Postural balance in children with cerebral palsy. Dev Med Child Neurol 2002;44:58-63.

4. Al-Nemr A, Abdelazeim F. Relationship of cognitive functions and gross motor abilities in children with spastic diplegic cerebral palsy. Appl Neuropsychol Child 2018;7:268-76.

5. Yokochi K. Gait patterns in children with spastic diplegia and periventricular leukomalacia. Brain Dev 2001;23:34-7.

6. Johari S, Rassafiani M, Dalvand H, Kahjoogh MA, Daemi M. Effects of maternal handling training at home, on development of fine motor skills in the children with cerebral palsy: A randomized clinical trial. J Occup Ther School Early Interv 2016;9:321-31.

7. Rogers S. Common conditions that influence children's participation. In: Case-Smith J, O’Brein JC, editors. Occupational Therapy for Children and Adolescents. St Louis: Elsevier; 2010.p.146-92.

8. Lieber RL, Steinman S, Barash IA, Chambers H. Structural and functional changes in spastic skeletal muscle. Muscle Nerve 2004;29:615-27.

9. Himmelmann K, Beckung E, Hagberg G, Uvebrant P. Gross and fine motor function and accompanying impairments in cerebral palsy. Dev Med Child Neurol 2006;48:417-23.

10. Mülazimoğlu Ballı Ö, Gürsoy F. The Study of Validity and Reliability of BruininksOseretsky Motor Proficiency Test for Five-Six- YearsOld Turkish Children. Hacettepe J Sport Sci 2012;23:104-18.
11. Bruininks VL, Bruininks RH. Motor proficiency of learning disabled and nondisabled students. Percept Mot Skills 1977;44:1131-7.

12. Gregory V, Payne L, Isaacs D. Human motor development: A lifespan approach. Boston: McGraw-Hill; 2005.

13. Deitz JC, Kartin D, Kopp K. Review of the Bruininks-Oseretsky Test of Motor Proficiency, Second Edition (BOT-2). Phys Occup Ther Pediatr 2007;27:87-102.

14. Köse B. Bruininks-Oseretsky motor yeterlik testi 2 kısa formunun Türkçe uyarlaması ve özgül öğrenme güçlüğü olan çocuklarda geçerlilik ve güvenilirliği. Ankara: Hacettepe Üniversitesi; 2018.

15. Bruininks RH, Oseretsky BD. Bruininks-Oseretsky test of motor proficiency second edition, brief form. Second ed. Bloomington: PsychCorp; 2010.

16. Romeo DM, Cioni M, Battaglia LR, Palermo F, Mazzone D. Spectrum of gross motor and cognitive functions in children with cerebral palsy: gender differences. Eur J Paediatr Neurol 2011;15:538.

17. Lee YC, Wu CY, Liaw MY, Lin KC, Tu YW, Chen CL, et al. Developmental profiles of preschool children with spastic diplegic and quadriplegic cerebral palsy. Kaohsiung J Med Sci 2010;26:341-9.

18. Arnould C, Bleyenheuft Y, Thonnard JL. Hand functioning in children with cerebral palsy. Front Neurol 2014;5:48.

19. Hintz SR, Kendrick DE, Vohr BR, Kenneth Poole W, Higgins RD; Nichd Neonatal Research Network. Gender differences in neurodevelopmental outcomes among extremely preterm, extremelylow-birthweight infants. Acta paediatr 2006;95:1239-48.

20. Tonak HA, Kılıç MC, Karadeniz Yenilmez Ö, Kitiş A. The Examination of Upper Extremity Functionality in Children with Cerebral Palsy. Aydın J Health Sci 2016;2:37-50.

21. Park MO. Effects of gross motor function and manual function levels on performance-based ADL motor skills of children with spastic cerebral palsy. J Phys Ther Sci 2017;29:345-8.

22. Franki I, Desloovere K, De Cat J, Feys H, Molenaers G, Calders P, et al. The evidence-base for conceptual approaches and additional therapies targeting lower limb function in children with cerebral palsy: a systematic review using the ICF as a framework. J Rehabil Med 2012;44:396-405.

23. Rabinowicz T, Petetot JMC, Gartside PS, Sheyn D, Sheyn T, de MyersGabrielleM C. Structure of the cerebral cortex in men and women. J Neuropathol Exp Neurol 2002;61:46-57.

24. Soyuer F, Türkmen MC, Cankurtaran F, Şırayder U, Öztürk A. Adölesan diparetik ve hemiparetik serebral palsililerde dinamik denge ve vücut kütle indeksi ile ilişkisi. J Exerc Ther Rehabil 2018;5:53-8.

25. Romeo DM, Sini F, Brogna C, Albamonte E, Ricci D, Mercuri E. Sex differences in cerebral palsy on neuromotor outcome: a critical review. Dev Med Child Neurol 2016;58:809-13.

26. Bisagno V, Bowman R, Luine V. Functional aspects of estrogen neuroprotection. Endocrine 2003;21:33-41.

27. Bax M, Tydeman C, Flodmark O. Clinical and MRI correlates of cerebral palsy: the European Cerebral Palsy Study. JAMA 2006;296:1602-8. 
28. Ko JY, Woo JH, Her JG. The reliability and concurrent validity of the GMFCS for children with cerebral palsy. J Phys Ther Sci 2011;23:255-8.
29. Bumin G, Kavak ST. An investigation of the factors affecting handwriting performance in children with hemiplegic cerebral palsy. Disabil Rehabil 2008;30:1374-85. 